\title{
The Effectiveness of the Chemistry Problem Based Learning (PBL) via FB among Pre-University Students
}

\author{
Mohd Shahir Mohamed Sunar ${ }^{1} \nless$ \\ Ahmad Jelani Shaari ${ }^{2}$ \\ 'Kolej MARA Kuala Nerang, Malaysia \\ Email:shahir.sunar@mara.gov.my Tel:+6047867255 \\ ${ }^{2}$ Universiti Utara Malaysia, Malaysia \\ Email:jelani@uum.edu.my
}

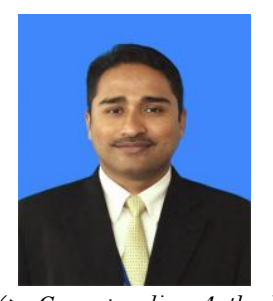

Corresponding Author)

\begin{abstract}
The impact of social media, such as Facebook in various fields including education is undeniable. The main objective of this study is to examine the effect of the interaction between students' learning styles and learning approaches on their achievements in the chemistry subject using the Problem-Based Learning (PBL) method through Facebook. The sample of this study consisted of 120 MARA College students, who were randomly selected to undergo PBL treatment via Facebook for nine weeks. This quantitative study used the $4 \times 2$ factorial experimental design. The main variables were the students' learning styles (visual, aural, reading-writing, and kinaesthetic) and learning approaches (surface learning and deep learning) as well as the interaction between both on their achievement in the final examination for chemistry subject. The two-Way ANOVA test results showed that the main effect of students' learning styles on their achievement in chemistry was significant across students' learning approach using PBL via Facebook. Furthermore, the Post-Hoc test had found that the mean for the reading-writing style of learning was significantly better than for other learning styles. Similarly, the main effect of learning approaches was also found to be significant across students' learning styles. It was found that the mean value for the deep learning approach was significantly higher than the mean value for the surface learning approach using the PBL method via Facebook. However, the effect of the interaction between these two independent variables (learning styles and learning approaches) on students' achievement was not significant.
\end{abstract}

Keywords: VARK learning style, Deep learning approach, Surface learning approach, Facebook, Problem-based learning method.

Citation | Mohd Shahir Mohamed Sunar; Ahmad Jelani Shaari (2017). The Effectiveness of the Chemistry Problem Based Learning ts. Journal of Education and e-Learning Research, 4(4): 129-138.

History:

Received: 20 October 2017

Revised: 10 November 201

Accepted: 13 November 2017

Published: 16 November 201

Licensed: This work is licensed under a Creative Commons

Attribution 3.0 License (cc))

Publisher:Asian Online Journal Publishing Group
Contribution/Acknowledgement: Both authors contributed to the conception and design of the study.

Funding: This study received no specific financial support.

Competing Interests: The authors declare that they have no conflict of interests.

Transparency: The authors confirm that the manuscript is an honest, accurate, and transparent account of the study was reported; that no vital features of the study have been omitted; and that any discrepancies from the study as planned have been explained.

Ethical: This study follows all ethical practices during writing.

\section{Contents}

1. Introduction

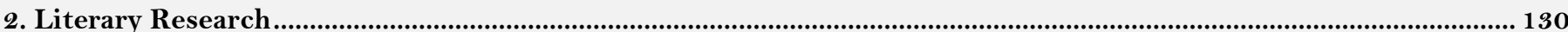

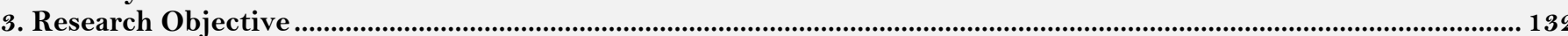

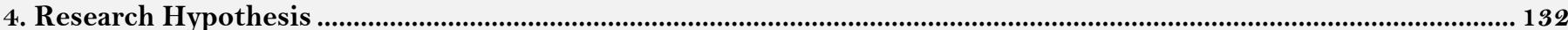

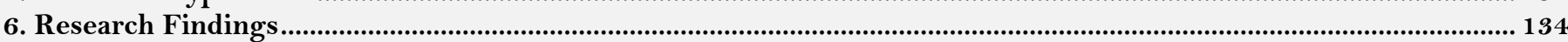

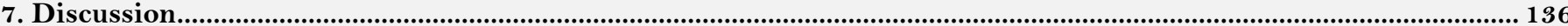

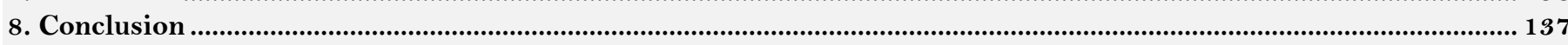

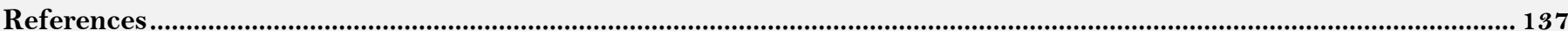




\section{Introduction}

The rapid development and widespread use of Web 2.0 Technology such as blogs, Flickr, YouTube, MySpace, Facebook, Twitter, Whatsapp etc sees transformation happening in all aspects of life such as politics, economy, education, social, method of acquiring information and also work culture. Most people use Facebook to send messages, upload and download music and videos, share information, update their online profile, send photos, send e-mails and all sorts of other activities (Rainie, 2009). Facebook emerged as the most popular social media platform in the world in a short period, reaching up to 500 million active users in July 2010, only six years after its inception (Paul, 2010). The number is found to continue rising fast and on 4 October 2012, the number of Facebook users reached 1 billion (Facebook.com, 2012). Up to Jun 2017, there are more than 2 billion active users on Facebook (Facebook.com, 2017).

The development of social media application is found to be popular amongst Malaysians as well, especially the younger generation. In a research by Syed et al. (2011) they found that Malaysian teenagers spend an average of 5 minutes to 3 hours daily to update their status, reading their friends' status updates, leaving comments, sending messages, and others. They also found that Facebook is the most popular social media among Malaysian students, followed by other social media platforms. The number of Facebook users in Malaysia has reached 15 million as of March 2015 (Socialbakers.com, 2015). This means that almost half of Malaysians has opened a Facebook account or owns an account. Teenagers between 18 to 24 years old have been identified as the biggest group of Facebook users in Malaysia, comprising of $34 \%$, followed by adults aged 25 to 34 years old, which represents $28 \%$ of the users (Socialbakers.com, 2015).

Facebook's status as the most popular social media platform among teenagers also rings true in Kolej MARA. In an initial survey done randomly on 100 Kolej MARA students, $99 \%$ has a Facebook account and only $1 \%$ (one student) did not own a Facebook account (Mohd and Ahmad, 2016). The tendency and frequency of Facebook usage among students has led the educators and researchers to study the suitability and effectiveness in using the social media platform in education (Tess, 2013). However, an empirical study on the effectiveness of social media usage in education is still in its infancy and has not been fully developed (Çevik, 2014; Sobaih et al., 2016). Social media like Facebook can be considered as part of education's interactive media as it allows interaction, exchange of opinion and feedback, and fits the learning criteria in the context of social learning (Kabilan et al., 2010; Manca and Ranieri, 2013; Sobaih et al., 2016).

The suitability of social media like Facebook to be integrated in the teaching and learning process is based on two famous social learning theories, i.e. Social Learning Theory (Bandura, 1977) and Sociocultural Learning Theory (Vygotsky, 1978). Social Learning Theory states that individuals, at their own initiative, will always be inclined to start and control their learning in order to achieve their desired learning outcomes. This theory also emphasized on learning interaction with friends by looking at learning as a social process where each individual will interact with their peers, the models and their surrounding situation. On the other hand, the Sociocultural Learning Theory states that the learning process must give more focus on social, language and cultural interaction. This theory emphasizes on a learning process that is not only seen as a process involving individuals but it is also an individual development process in a social environment sphere (Hung, 2002). Some early research by Tess (2013) and Çevik (2014) have suggested learning implementation integrated with social media in learning methods that are active, student-centric and contemporary, such as problem-based learning. Through this method, the students' level of thinking is expected to be more critical and encourages deeper knowledge building (Tess, 2013). However, the question remains on whether the integration of social media in learning would be able to fulfil the different backgrounds of the students, and there are not enough research done to answer that question. Thus, this research was done to study the effects of problem-based learning methods integrated with Facebook in learning chemistry in Kolej MARA, taking into consideration the students' learning styles (using the VARK learning style) and learning approach adopted by the students.

\section{Literary Research}

\subsection{The VARK Learning Style}

Learning style refers to the methods usually used by individual students in their learning process (Hawk and Shah, 2007). According to Jantan and Razali (2002) who looked at learning styles from a psychology perspective, learning styles are the students' way of staying in focus when studying. Looking on the cognitive side however, learning styles refers to the various methods to create individualistic perception on the effectiveness of information processing which will lead to the formation of concept and principals (Fleming and Baume, 2006). There are various learning style models introduced in earlier studies, such as Kolb's Learning Styles and Experiential Learning Model, Gregorc's Learning Style Model, the VARK Learning Style Model, the Felder and Silverman Learning Style Model, the Dunn \& Dunn Model and the RASI Model.

According to the Kementerian Pendidikan Malaysia (2008) there are two types of learning style models frequently used for national level students, namely the VARK Learning Style Model and Dunn \& Dunn. These learning style models are chosen as they have moderately high validity and credibility support values, and accessible as they are web-based (Hawk and Shah, 2007). The VARK Learning Style model was initially known as the VAK Model but Fleming has modified it to VARK in 2006. The VARK Learning Style Model classified students into four different learning styles, based on different sensory inclinations known as visual (V), aural (A), read \& write $(\mathrm{R})$ and kinaesthetic $(\mathrm{K})$, which is how the learning style model got its name. According to Ismail (2010) classifying students based on different modes of learning is crucial to identify the teaching effectiveness of certain subjects on students who adopt the VARK learning model.

\subsection{Learning Approach}

Learning approach is a concept that explains a student's acceptance and perception on a given subject or assignment (Ramsden, 1992). According to Watkins (1982) there are two types of learning approaches; the deep learning approach and the surface learning approach. If the student has a positive perception on a subject, they will adopt a deep learning approach, but on the other hand, if they have a negative perception on a subject, they will 
adopt a surface learning approach (Ramsden, 1992). The student will consciously pick a deep or surface learning method, and the implication of the choice is important in determining the results of the student's achievement, apart from the learning method used (Biggs et al., 2001). This condition is due to the learning approach being a basic concept that takes into consideration the learning process and the quality of the learning results (Duff et al., 2004). For the students who chose the surface learning approach, they will carry out a learning assignment by putting out merely a passable or minimum grade as their target (Biggs and Moore, 1993). The student sees this learning approach as balancing between not needing to work too hard and at the same time not failing the subject. For the deep learning approach, the student would have an intrinsic interest to understand the concepts and meanings of certain subjects and it builds their competency in the subject (Biggs, 1987). According to Newble and Hejka (1991) students who adopt the deep learning approach are motivated by their interest on the subject. Hence, the strategy used is by understanding meanings and concepts through a lot of reading and connecting the knowledge learnt with existing knowledge and experience (Biggs, 1987) plus understanding the basic patterns and principles in a subject (Entwistle, 1997).

\subsection{Problem-Based Learning}

Problem-based learning was introduced by Howard S. Barrows and was first implemented in McMaster University in the medical field circa 1960s (Barrows and Tamblyn, 1980). Initially, the idea to implement problembased learning surfaced when it was found that most medical students at that time fail to apply their knowledge in actual clinical environment, despite getting excellent results in their finals. Problem-based learning was developed in an effort to prep students with a learning environment that is similar to actual clinical environment or practice. This kind of learning environment would be able to equip students with skills relevant in the real world as well as encouraging the students to adopt a deeper learning (Tan and Mohammad, 2014). It started with the medical field and now problem-based learning is also widely used in other fields in almost all universities around the world. In developed countries such as the United States of America, problem-based learning is not only practised in universities, but was also introduced in secondary schools from as early as the 1990s (Barrows and Kelson, 1993).

The problem-based learning method is also familiar to most students in Malaysian public and private universities. However, a research done by Tan and Mohammad (2014) found that this method is not widely practised in most universities in Malaysia, even though the method has been common knowledge for a while. Most university students were only introduced to problem-based learning when they enter university (Tan and Mohammad, 2014). In other words, this method was not exposed to students during their secondary school years and even during their pre-university programmes such as Sijil Tinggi Pelajaran Malaysia (STPM), matriculation or A-Levels (Hussain and Berhannudin, 2009; Tan and Mohammad, 2014). In fact, most students and teachers in Malaysian secondary schools have never thought of or even know about problem-based learning and how to implement them (Faaizah and Halimah, 2007).

The highlight of the literature done by the researchers also found the lack of research on studying the effectiveness of problem-based learning methods, either in the secondary school level or even in pre-university. This situation made it difficult for lecturers to implement the method in university, as the students do not have prior exposure to active learning. This is because the students came from a passive learning environment and are used to being spoon-fed by their teachers, plus the school system is too examinations-centric (Hussain and Berhannudin, 2009; Khairiyah et al., 2009; Tan and Mohammad, 2014). Based on this situation, there is a solid rationale or basis to introduce the problem-based learning method especially from the secondary school or preuniversity level. This would allow students to have knowledge and basic ability in problem-based learning process much earlier, which would prevent them from feeling awkward and nervous when given problem-based learning assignments when in university (Tan and Mohammad, 2014).

\subsection{Blended Learning Model through Social Media Using Problem-Based Learning Method.}

The problem-based learning method has gone through various transformations, moving concurrently with the ever-evolving technology. For example, the development of the Web 2.0 technology has allowed easier interaction and collaboration between students especially during the discussion process in order to find a solution to a certain problem (Treepuech, 2011; Sobaih et al., 2016). Social media (like Facebook), one of Web 2.0's most important technologies, has potential to facilitate the implementation of problem-based learning process (Wiboolyasarin, 2014). Further research has successfully developed learning models that used social media such as Facebook as a learning tool. For example, Blended Learning Model through Social Media Using Problem-Based Learning Method (Wiboolyasarin, 2014) has eight levels of learning, which are preparing, identifying, analysing, researching, creating, testing, gathering and evaluating. According to Manca and Ranieri (2013) the implementation of learning methods integrated with social media with active and contemporary learning methods such as problem-based learning is expected to increase the student's communications ability, creativity, collaborative ability in a group setting, and critical thinking.

Apart from that, Blended Learning Model through Social Media Using Problem-Based Learning Method also allows students to study at any time or place (Wiboolyasarin, 2014). Diagram 1.0 shows the flow chart of each activity based on the Blended Learning Model through Social Media Using Problem-Based Learning Method. 


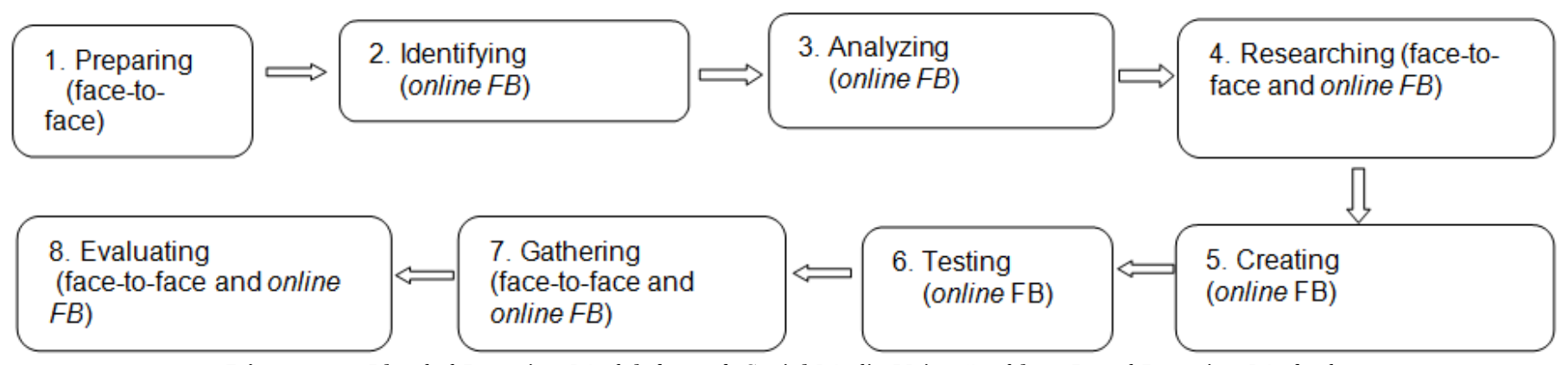

Diagram-1. Blended Learning Model through Social Media Using Problem-Based Learning Method.

\section{Research Objective}

In general, this research was carried out to identify the effectiveness of problem-based learning methods via Facebook to study chemistry among the students of Kolej MARA. This research also takes into consideration the background of the students' learning styles and approach. The effect of social media integration in learning chemistry will then be assessed through their achievement in the post-test, which will be done at the end of the learning semester. The specific objectives of this research are:

i. Identifying the effects of the students' learning styles (Visual, Aural, Read \& Write and Kinaesthetic) on chemistry subject results across the students' learning approach (deep and surface) in Kolej MARA through problem-based learning method via Facebook. (Main effect $\boldsymbol{A}$ )

ii. Identifying the students' learning approach (deep and surface) on chemistry subject results across the learning styles (Visual, Aural, Read \& Write and Kinaesthetic) in Kolej MARA through problem-based learning method via Facebook. (Main effect B)

iii. Identifying the students' learning style interaction (Visual, Aural, Read \& Write and Kinaesthetic) on chemistry subject results of Kolej MARA students who adopted the learning approach (deep and surface) through problem-based learning method via Facebook. (Interaction effect $\boldsymbol{A} \times \boldsymbol{B}$ )

\section{Research Hypothesis}

Referring to the specific research objectives, three null hypotheses were formulated, and they are:

First Hypothesis: No significant difference in the students' learning style (Visual, Aural, Read \& Write and Kinaesthetic) on chemistry subject results across the students' learning approach (deep and surface) in Kolej MARA through problem-based learning method via Facebook.

Second Hypothesis: No significant difference in the students' learning approach (deep and surface) on chemistry subject results across the learning styles (Visual, Aural, Read \& Write and Kinaesthetic) in Kolej MARA through problem-based learning method via Facebook.

Third Hypothesis: No significant difference in the students' learning style interaction (Visual, Aural, Read \& Write and Kinaesthetic) on chemistry subject results of Kolej MARA students who adopted the learning approach (deep and surface) through problem-based learning method via Facebook.

\section{Methodology}

\subsection{Research Design}

This research applied the quantitative method using the $4 \times 2$ factorial experimental design. The main effects studied were the VARK (Visual, Aural, Read \& Write and Kinaesthetic) learning styles and learning approach (deep and surface). The result of the interaction of the two variables were measured by the students' achievements in the semester two chemistry final examinations after undergoing problem-based learning methods through Facebook.

\subsection{Sampling Technique}

This research used the stratified random sampling method. Students were asked to answer the learning approach instrument while the VARK learning style was carried out online. Each student was then classified according to the two learning styles and approach and later chosen randomly (assign the treatment at random) to receive treatment on problem-based learning methods through Facebook in smaller groups. The gender factor was also taken into consideration so each small group formed has a balance of both males and females. There were eight treatment groups formed with 15 students who were randomly picked (refer to Table 1). The total number of students who took part in this research was 120 people, with 58 male students and 62 female students.

\begin{tabular}{l|l|l|l}
\hline \multicolumn{3}{c}{ Table-1. Research Group } \\
\hline \multicolumn{2}{l}{ Number of Students } & Learning Approach & VARK Learning Style \\
\hline 2. & 15 & Surface & Visual \\
\hline 3. & 15 & Surface & Aural \\
\hline 4. & 15 & Surface & Reading \& Writing \\
\hline 5. & 15 & Surface & Kinaesthetic \\
\hline 6. & 15 & Deep & Visual \\
\hline 7. & 15 & Deep & Aural \\
\hline 8. & 15 & Deep & Reading \& Writing \\
\hline \multicolumn{2}{l|}{ Source: Adapted from Wiersma $(2000)$} & Deep & Kinaesthetic \\
\hline
\end{tabular}




\subsection{Data Collection}

Data collection for this research consists of pre-test and post-test, problem-based learning activities for 11 Facebook groups and survey on students' learning style and approach.

\subsection{Pre-Test and Post-Test}

The pre-test for this research was from the mid-semester test while post-test is the semester's final examinations. Both pre- and post-tests tested the students' understanding on the topic and gauge its difficulty level. The questions were prepared by Kolej MARA lecturers, checked and verified by Universiti Kuala Lumpur (UniKL) lecturers.

\subsection{Student Facebook Chemistry PBL Group}

Students involved in this research were asked to join their respective Facebook groups as assigned by the lecturer. Problem-based learning (PBL) took place with the lecturer who is also a member of the group, but the lecturer only acted as the facilitator and monitored every student discussion.
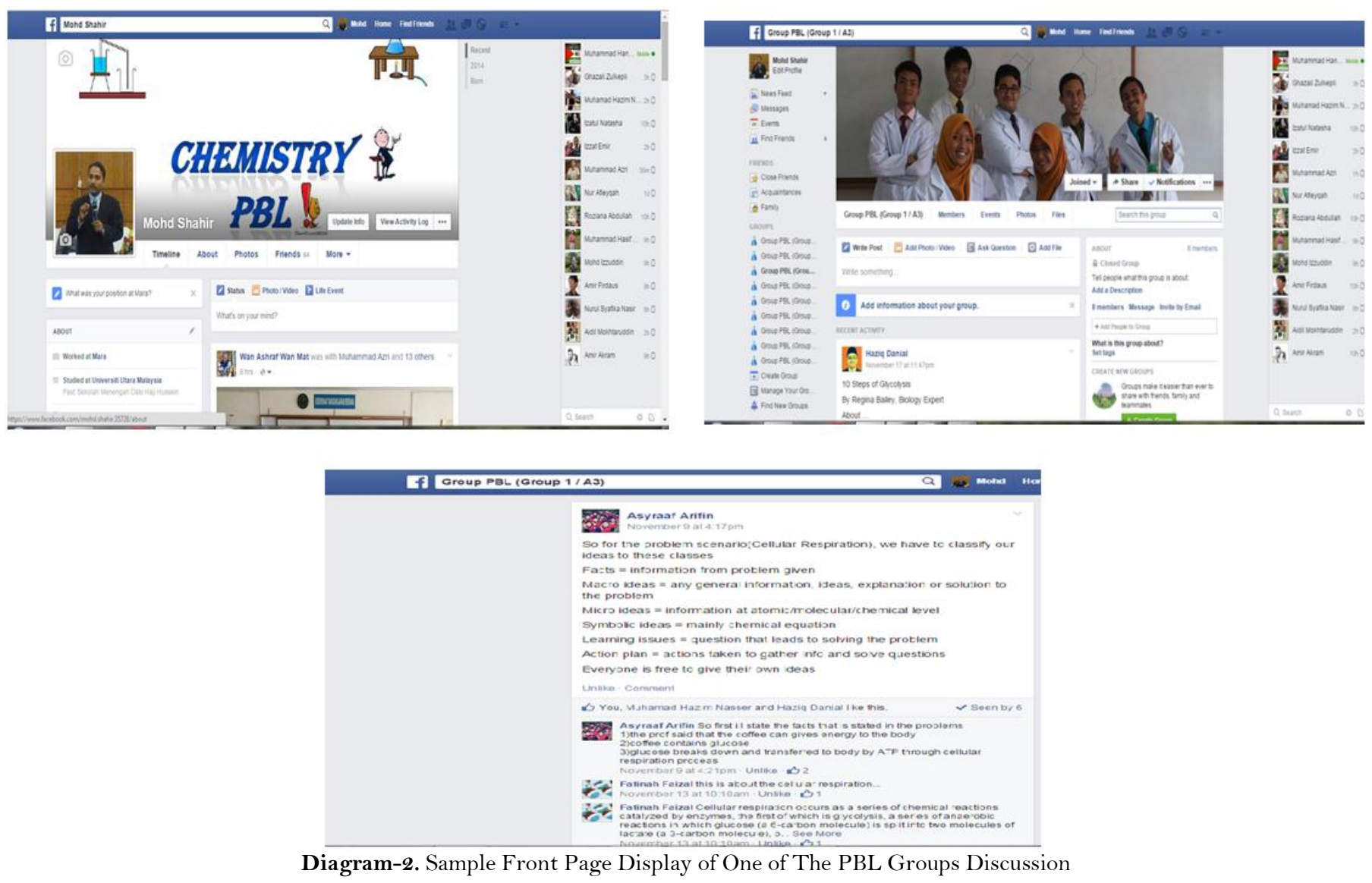

\subsection{Measure of VARK Learning Style and Student Learning Approach}

The students' learning styles were measured using the VARK Learning Style Version 7.0 instrument (Flemming and Charles, 2004) which has 16 items. Meanwhile, The Revised Two Factor Study Process Questionnaire (R-SPQ-2F) instrument was used to measure the students' learning approach (Biggs et al., 2001). This instrument has 20 items in total with each learning approach (deep and surface) has 10 items.

\subsection{Research Procedure}

The duration of the treatment was one semester (18 weeks) where in the first nine weeks, students went through learning through face-to-face instruction without using social media. However, during that period, students were exposed and introduced to problem-based learning methods. They then sat for their mid-semester examinations in the ninth week and this exam paper was used as the pre-test in this research. The following week, i.e. week 10 until week 18 (nine weeks), the students went through problem-based learning process through social media and face-to-face instruction. Diagram 3 shows the research procedure implemented. 
Week One Till Eight

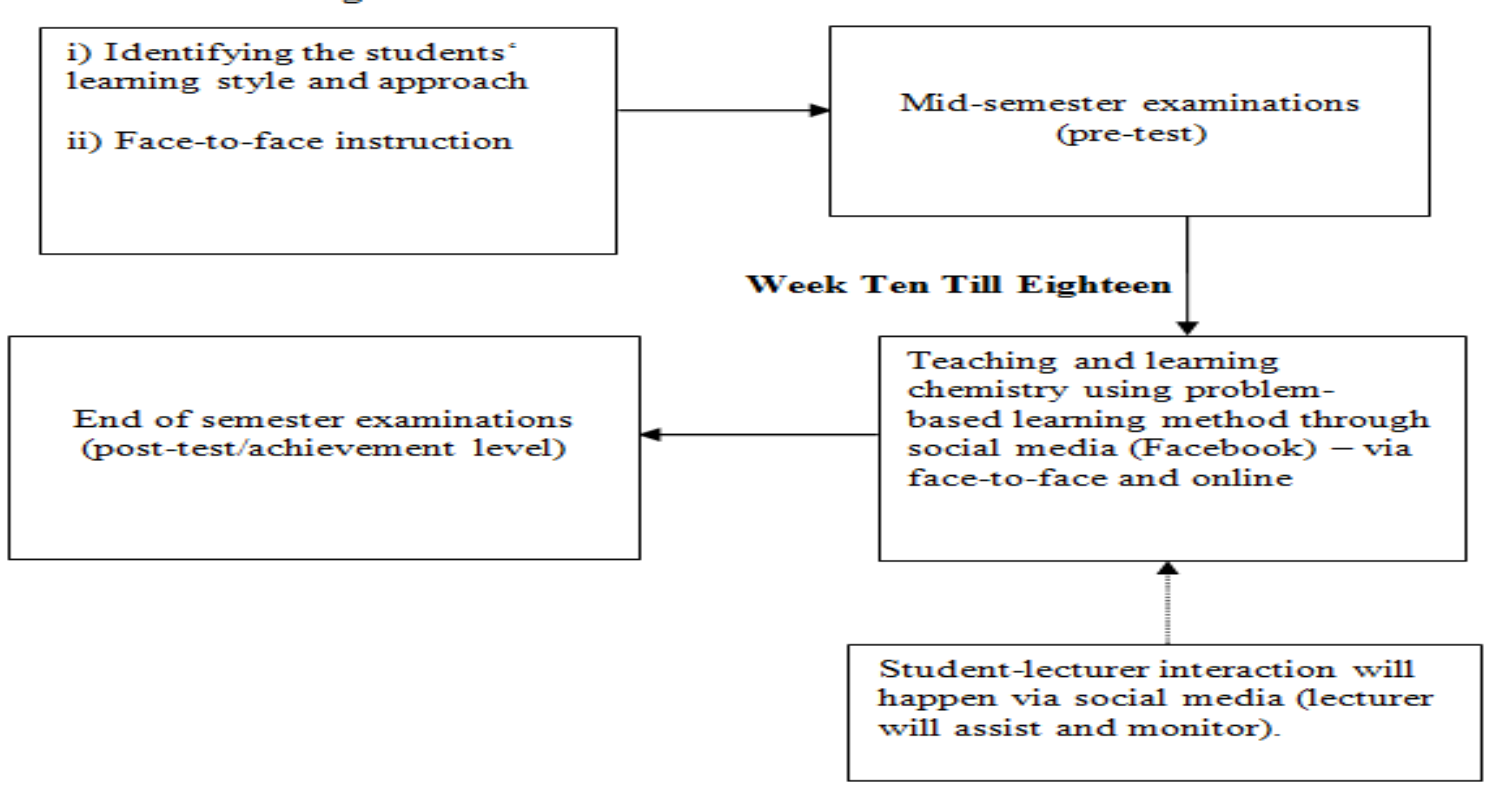

Diagram-3. Research Implementation Procedure

\subsection{Chemistry PBL via Facebook Learning Process}

The Chemistry PBL via Facebook Learning Process was based on the Blended Learning Model through Social Media Using Problem-Based Learning Method that was introduced by Wiboolyasarin (2014). There were eight main phases based on the model, namely preparing, identifying, analysing, researching, creating, testing, gathering and evaluating. Stated below is the explanation for the activities in each phase, sorted by week:

1. Preparing (first week): At this stage, the lecturer has already explained the learning objectives, learning activities, evaluation process and communication means that could be done via Facebook. Problem scenarios were also given to each group and this activity was done face-to-face

2. Identifying (second week): Students were asked to study the problem's situation, to discuss, and to list down as many ideas to address the problem. The activity was done online on Facebook.

3. Analysing (third week): Planning to collaborate, doing job distribution, problem analysis and planning problem solving. The activity was done online on Facebook.

4. Researching (fourth and fifth week): Students did their studying, searching, researching and information gathering from various sources. The activity was done face-to-face and online on Facebook.

5. Creating (sixth week): Students come up with their hypothesis based on information gathered and their existing knowledge and experience. The activity is done online on Facebook.

6. Hypothesis testing (seventh week): Students discussed and exchanged information before the information was used to test the hypothesis. The activity was done online on Facebook.

7. Summarising (eighth week): Each group was asked to do a summary on the ideas, approach and analysis done in solving a problem. Each report was uploaded to the Chemistry PBL Facebook page and other team members will have given their opinions and comments on the work of other groups. The activity was done face-to-face on Facebook.

8. Evaluating (ninth week): Each group presented their research findings (solution) to the problem statement received. Fellow students from other groups were allowed to voice their opinions. The lecturer will have given his/her comments and evaluation, including on the cooperation of each team member in a group. The activity was done face-to-face and online on Facebook.

\section{Research Findings}

This research used the statistical analysis from the Two-Way Analysis of Variance (ANOVA) test based on the previously mentioned hypotheses. However, before the Two-Way ANOVA test was used, a few necessary conditions were first checked such as normality (scores in normal scattered population), random sampling, sample size and homogeneity of variance.

Table-2. Mean and Standard Deviation of Student Achievement in Chemistry Based on Learning Style (Visual, Aural, Read \& Write, Kinaesthetic) and Learning Approach (Deep and Surface)

\begin{tabular}{l|l|l|l|l}
\hline Learning Style & Learning Approach & Min & SD & N \\
\hline Visual (V) & Deep & 86.40 & 7.48 & 15 \\
\hline \multirow{2}{*}{ Aural (A) } & Surface & 77.67 & 8.53 & 15 \\
& Total & 82.03 & 9.05 & 30 \\
\hline \multirow{2}{*}{ Read \& Write (R) } & Deep & 86.27 & 6.56 & 15 \\
\cline { 2 - 5 } & Surface & 80.33 & 9.37 & 15 \\
\hline \multirow{2}{*}{ Kinaesthetic (K) } & Total & 83.30 & 8.50 & 30 \\
\hline & Deep & 86.60 & 7.38 & 15 \\
\cline { 2 - 5 } & Surface & 87.87 & 6.95 & 15 \\
\hline \multirow{2}{*}{ Total } & Total & 87.23 & 7.07 & 30 \\
\hline & Deep & 87.67 & 4.91 & 15 \\
\cline { 2 - 5 } & Surface & 83.00 & 6.89 & 6.34 \\
\hline
\end{tabular}

Source: Adapted from Wiersma (2000) 
After all the conditions were met, the researcher would then proceed with the statistical test on each research hypothesis. Factorial analysis (Two-Way ANOVA) $2 \times 4$ was used to analyse the data using the Simple Main Effect Tests and the Tukey Pairwise Comparisons for mean comparison [family error rate for Tukey set at 0.05]. Table 2.0 shows the mean and standard deviation for all learning style combination groups (visual, aural, read $\&$ write, kinaesthetic) and learning approach (deep and surface) towards the achievement in chemistry. Table 3.0 shows the Two-Way ANOVA results of learning style and learning approach on the achievement in Chemistry.

Table-3. ANOVA Analysis on the Effect of Learning Style and Learning Approach towards Achievement in Chemistry.

\begin{tabular}{l|l|l|l|l|l}
\hline Source & DF & PT & PTM & F & Sig \\
\hline Learning Style (A) & 3 & 470.63 & 156.88 & 2.89 & .037 \\
\hline Learning Approach (B) & 1 & 612.01 & 612.01 & 11.28 & .001 \\
\hline Learning Style*Learning Approach (A X B) & 3 & 399.43 & 133.14 & 2.45 & .067 \\
\hline Error & 112 & 6075.87 & 54.25 & & \\
\hline Total & 120 & 863881.00 & & & \\
\hline *significance level 0.05 & & & \\
\hline $\begin{array}{l}\text { DF = Degree of Freedom PT = Power of Two MPT = Min Power of Two } \\
\text { F = F Statistic }\end{array}$
\end{tabular}

6.1. The Effect of the VARK Learning Style on the Achievement in Chemistry across the Students' Learning Approach through Problem-Based Learning Method via Facebook

Table 4.0 shows the findings of post-test results based on the students' VARK learning style. Statistical test (Table 4.0) shows the significant effects of learning styles (visual, aural, read \& write, kinaesthetic), $\mathrm{F}(3,112)=2.89$, $\mathrm{p}<0.05$. This result has successfully negated the first hypothesis. This shows that the learning style gives a different effect on the students' achievement in Chemistry across their adopted learning approach.

Table-4. Findings of the post-test results based on students' VARK learning style

\begin{tabular}{l|l|l|l|l|l|l}
\hline Learning Style & N & min & sd & df $\mathbf{1}$ & F & p \\
\hline Visual & 30 & 82.03 & 9.05 & 3 & 2.89 & .03 \\
\hline Aural & 30 & 83.30 & 8.50 & 3 & & \\
Read \& Write & 30 & 87.23 & 7.07 & 3 & & \\
Kinaesthetic & 30 & 85.33 & 6.34 & 3 & & \\
\hline
\end{tabular}

A follow-up post-hoc test was also conducted to examine the mean difference between all four learning style categories (visual, aural, read \& write and kinaesthetic). Research findings (Table 5) shows that there is a significant mean difference for achievement in Chemistry between students who adopted the visual learning style and those who adopted the read \& write learning style. On the other hand, there is no significant mean difference between other learning styles (refer to Table 5)

Table-5. Post-hoc Test follow-up analysis for the difference in achievement in chemistry between the students' learning styles (visual, aural, read \& write and kinaesthetic).

\begin{tabular}{l|l|l|l|l}
\hline Learning Styles (I) & Learning Styles (J) & Different Min (I-J) & Standard Error & Significance \\
\hline \multirow{3}{*}{ Visual } & Aural & -1.27 & 2.018 & .92 \\
& Read \& Write & $-5.20^{*}$ & 2.018 & .05 \\
& Kinaesthetic & -3.30 & 2.018 & .36 \\
Aural & Visual & 1.27 & 2.018 & .92 \\
& Read \& Write & -3.93 & 2.018 & .21 \\
& Kinaesthetic & -2.03 & 2.018 & .75 \\
\hline \multirow{3}{*}{ Read \& Write } & Visual & $5.20^{*}$ & 2.018 & .05 \\
& Aural & 3.93 & 2.018 & .21 \\
& Kinaesthetic & 1.90 & 2.018 & .78 \\
Kinaesthetic & Visual & 3.30 & 2.018 & .36 \\
& Aural & 2.03 & 2.018 & .75 \\
*significance level at 0.05 & -1.90 & & 2.018 & .78 \\
\hline
\end{tabular}

*significance level at 0.05

6.2. The Effects of Learning Approach on Achievement in Chemistry across Students' VARK Learning Styles using the Problem-Based Learning Method via Facebook

The ANOVA statistical test result (Table 6) also showed a significant effect of the learning approach (deep and surface), $\mathrm{F}(1,112)=11.28, \mathrm{p}<0.05$. This result has successfully negated the second hypothesis. The main effect of deep learning approach towards the achievement in Chemistry is significantly higher as compared to the mean of surface learning approach. This means that the choice of learning approach also gives different effects on the students' achievement in chemistry across their learning styles.

Table-6. Findings of post-test achievement based on learning approach

\begin{tabular}{l|l|l|l|l|l|l}
\hline Learning Approach & N & min & sd & df1 & F & p \\
\hline Surface & 60 & 82.2 & 8.68 & 1 & 11.28 & $.00^{*}$ \\
\hline Deep & 60 & 86.7 & 6.51 & 1 & & \\
\hline *p $<.05$ & 120 & & & & & \\
\hline
\end{tabular}


6.3. The Effect of VARK Learning Style on the Achievement in Chemistry among Kolej MARA Students Who Adopted the Learning Approach (Deep and Surface) through Problem-Based

\section{Learning Method via Facebook}

Effect of the interaction between both free variables (VARK Learning Style*Learning Approach) on the dependent variable (student achievement) using problem-based learning method via Facebook was found to be insignificant with $\mathrm{F}(3,112)=2.45, \mathrm{p}>0.05$. This result was unsuccessful in negating the third hypothesis. This means that the interaction of the two free variables (VARK learning style and learning approach) did not give a significant impact towards student achievement in chemistry through problem-based learning method via Facebook. Diagram 4 shows the detailed mean achievement in chemistry for the interaction between VARK learning style and learning approach.

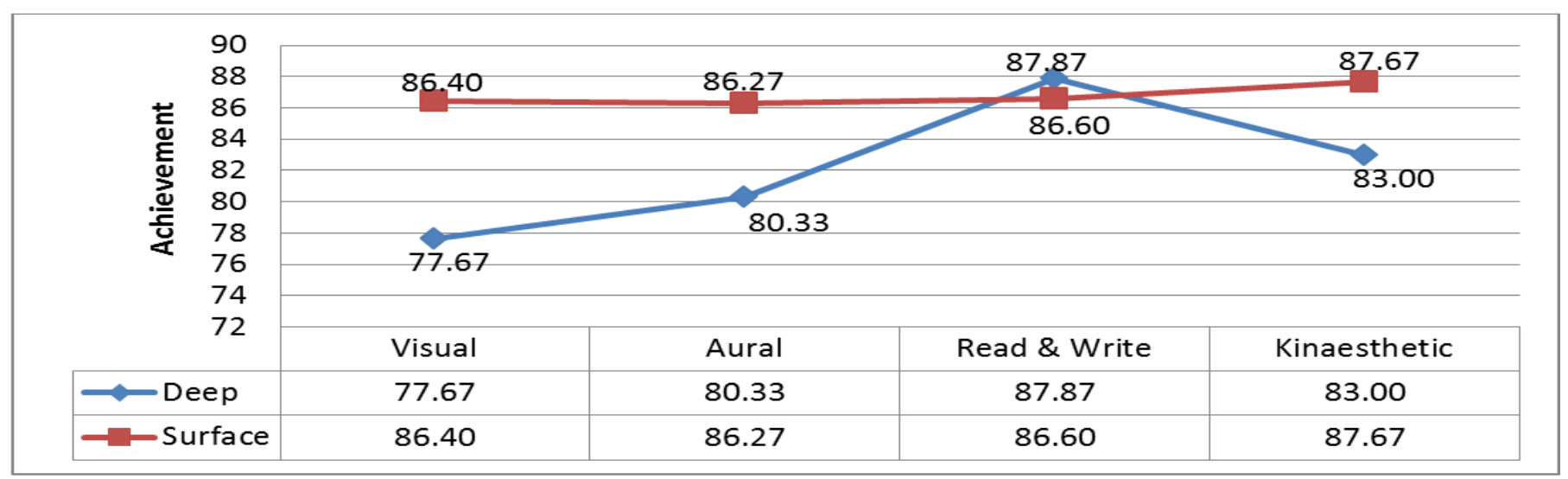

Diagram-4. Mean achievement in chemistry for the interaction between learning approach (deep and surface) and student learning style (visual, aural, read \& write and kinaesthetic).

\section{Discussion}

The ANOVA test result for free samples shows the main effects of the learning style free variable, $\mathrm{F}(3,112)=$ 2.89, $\mathrm{p}<0.05$ towards the dependent variables of achievement in chemistry. Hence, this result has successfully negated the formed hypothesis. Based on the ANOVA test analysis, the mean for the read \& write learning style free variable is 87.23 , $(\mathrm{SP}=7.07)$ surpassing visual with mean of $82.03(\mathrm{SP}=9.05)$, aural with mean of $83.30(\mathrm{SP}=$ $8.50)$ and kinaesthetic with mean of $85.33(\mathrm{SP}=6.34)$. The Post-Hoc test showed the mean of students who adopted the read and write learning style is significantly better than those who adopted the visual learning style across learning approach through problem-based learning method via Facebook. On the other hand, there no significant differences between the mean of students who adopted other learning styles. This research finding is in line with the research done by Ramirez (2011) and Moayyeri (2015) who found that students who adopted the unimodal read-write learning styles achieved significantly better as compared to those who adopted other learning styles. In the study by Ramirez (2011) two types of test questions, namely objective questions and arithmetic questions, were given to the students with different learning styles. For the arithmetic questions, students who adopted the read and write learning styles received the highest grades (mean $=6.3)$ as compared to visual $($ mean $=$ $4.9)$, kinaesthetic $($ mean $=4.7)$ and aural $($ mean $=3.7)$. However, for objective questions, it was found that there are no significant differences shown by all four learning style groups (visual, aural, read \& write and kinaesthetic).

There is also a research by Moayyeri (2015) involving 360 undergraduate students who were randomly chosen from four different faculties. The findings by Moayyeri $(2015)$ is in line with this research as students who adopted the read \& write learning style showed the highest academic achievement as compared to other learning styles. Meanwhile, the visual learning style showed the lowest academic achievement. It is clear that the research done by Ramirez (2011) and Moayyeri (2015) showed the same findings with this research with the read \& write learning style showing the highest achievement. In terms of the learning style that showed a low academic achievement, the findings of this research is in line with the research by Moayyeri (2015) with the visual learning style acquiring the lowest achievement as compared to other learning styles. However, the result is different from the finding of Ramirez (2011) who found that the aural learning style showed the lowest academic achievement.

Apart from that, for the main effect of the students' learning approach variable, the mean for deep learning approach $($ mean $=86.7)$ surpassed the mean for surface learning approach $($ mean $=82.2)$. This significantly shows that students who adopted the deep learning approach achieved better results as compared to students who adopted the surface learning approach after undergoing problem-based learning method via Facebook. This finding is in line with prior research (Entwistle and Ramsden, 1983; Abdul, 2004; Gomes, 2011; Armstrong, 2014; Liu et al., 2014) which found that students who adopted the deep learning approach will achieve better results as compared to those who adopted the surface learning approach. However, other factors could influence the students' choice of learning approach. For example, Abdul (2004) found that the age factor influenced the choice of learning approach, with the older students were more inclined to adopt the deep learning approach as opposed to their younger counterparts. Thus, the older students will achieve better results and understand a certain subject in greater detail (Abdul, 2004). The same goes for the research by Gomes (2011) who found that there are differences in terms of the learning approach selection pattern based on their year of study, whereby students with higher study years were more inclined to choose the deep learning approach. The finding of Armstrong (2014) found that the teaching strategy factor could influence that selection of learning approach among the students, which in turn will determine the student's academic achievement in certain subjects. For this research, the age factor did not influence the findings of this research since all of the students are of the same age, excluding the one lecturer who was assigned to teach. Thus, the research findings clearly shows that problem-based learning method via Facebook is suitable for implementation for students who adopts the deep learning approach as compared to students who adopts the surface learning approach. 
Next, the ANOVA statistical test shows that there are no significant interaction effect, $\mathrm{F}(3,112)=2.45, \mathrm{p}>0.05$ on the achievement in chemistry between the learning style (visual, aural, read \& write and kinaesthetic) with the student's learning approach (deep and surface). The research findings are in line with prior research (Newble and Entwistle, 1986; Liew et al., 2015). The research by Newble and Entwistle (1986) was one of the earliest research done regarding the correlation between learning approach and learning style on the students' academic achievement. The Newble and Entwistle (1986) research found no significant difference for the summative test achievement among students who adopted a combination of different learning styles and learning approach. The same goes for the research by Liew et al. (2015) who found that the interaction between learning styles and learning approach did not produce a significant effect on learning results, which were evaluated through summative examinations. The research, which was done on medical students, used the VARK instrument to detect their learning styles while the ASSIST (Approaches and Study Skills Inventory for Students) instrument was used to test the learning approach adopted by the students. However, there were research done which found that interaction between deep learning approach with any learning styles would result in better academic results. The findings of the research were contrary to the findings of this research. For example, the findings of the research by McManus et al. (1998) and the findings of the research by Ward (2011) found the existence of the effect of interaction between deep learning approach with learning style, but the opposite happens where there are no effects of interaction between surface learning approach with learning style.

\section{Conclusion}

This research finds that achievement in chemistry for students who adopted the reading and writing style is higher and is significantly different as compared to other learning styles across learning approaches using the PBL via Facebook method. The same goes to the students' learning approach, where it is found that the deep learning approach recorded higher marks and are significantly different as compared to students adopting surface learning approach across the students' learning styles.

Apart from that, problem-based learning methods via social media, Facebook in particular, for the study of chemistry should be initiated in an earlier stage (for example, during the pre-university level). This is due to the fact that early exposure to problem-based learning methods helps students to apply their knowledge or theories learnt in class, in the real world. Early exposure also would be able to help students to familiarise themselves with the methods before learning about them in university afterwards.

\section{References}

Abdul, R.H., 2004. Student study approach preferences and motivation in teacher training in Malaysia. PhD Thesis. University of Surrey, United Kingdom.

Armstrong, P.G., 2014. The effects of students' approach to learning and instructional strategy (Delivery) on academic success. PhD Thesis. Capella University.

Bandura, A., 1977. Social learning theory. Englewood Cliffs, New Jersey: Prentice-Hall.

Barrows, H.S. and A. Kelson, 1993. Problem-based learning in secondary education and the problem-based learning institute. Springfield, IL: Southern Illinois University School of Medicine.

Barrows, H.S. and R.M. Tamblyn, 1980. Problem-based learning: An approach to medical education. New York: Springer Publishing Company.

Biggs, J., D. Kember and D.Y.P. Leung, 2001. The revised two-factor study process questionnaire: R-SPQ-2F. British Journal of Educational Psychology, 7 1(1): 133-149. View at Google Scholar | View at Publisher

Biggs, J.B., 1987. Student approaches to learning and studying. Hawthorn, Victoria: Australian Council for Educational Research.

Biggs, J.B. and P.J. Moore, 1993. The process of learning. 3rd Edn., New York: Prentice Hall.

Çevik, Y.D., 2014. Teacher training through social networking platforms : A case study on facebook. Computers in Human Behavior, 30(6): 714-727. View at Google Scholar | View at Publisher

Duff, A., E. Boyle, K. Dunleavy and J. Ferguson, 2004. The relationship between personality, approach to learning and academic performance. Personality and Individual Differences, 36(8): 1907-1920. View at Google Scholar |View at Publisher

Entwistle, N., 1997. Reconstituting approaches to learning: A response to webb. Higher Education, 33(2): 213-2 18. View at Google Scholar

Entwistle, N.J. and P. Ramsden, 1983. Understanding student learning. London: Croom Helm.

Faaizah, S. and B.Z. Halimah, 2007. C2HADAM: Hybrid PBL multimedia and web based courseware for science. Paper Presented at the International Conference on Science and Mathematics in Education (CoSMEd), SEAMEO RECSAM, Penang, Malaysia.

Facebook.com, 2012. One billion people on facebook. Retrieved from http://newsroom.fb.com/News/457/One-Billion-People-on-Facebook.

Facebook.com, 2017. Facebook reports first quarter 2017 results. Retrieved from http://investor.fb.com/releasedetail.cfm?ReleaseID=780093.

Fleming, N.D. and D. Baume, 2006. Learning styles again: Varking up the right tree! Educational Developments, 7(4): 4. View at Google Scholar

Flemming, N.D. and C.B. Charles, 2004. VARK, a guide to learning styles. Retrieved from http://edorigami.wikispaces.com/ICT+and+LEARNING+STYLES.

Gomes, C.M.A., 2011. Deep and surface approach to learning: Different perspectives about academic achievement. Psicologia: Reflexao e Critica, 24(3): 438-447. View at Google Scholar

Hawk, T.F. and A.J. Shah, 2007. Using learning style instruments to enhance student learning. Decision Sciences Journal of Innovative Education, 5(1): 1-19. View at Google Scholar | View at Publisher

Hung, D., 2002. Bringing communities of practice into schools: Implications for instructional technologies from Vygotskian perspectives. International Journal of Instructional Media, 29(2): 171-183. View at Google Scholar

Hussain, O. and S.M. Berhannudin, 2009. First year students first year PBL experience in a large class. Paper Presented at the International Symposium on PBL 2009, Republic Polytechnic, Singapura.

Ismail, I.M., 2010. Maklum balas pelajar melalui gaya pembelajaran VARK terhadap pengajaran berasaskan komputer (PBK). Master Thesis in Education, Universiti Tun Hussein Onn Malaysia, Batu Pahat.

Jantan, R. and M. Razali, 2002. Psikologi Pendidikan Pendekatan Kontemporari. Kuala Lumpur: McGraw Hill Educa tion.

Kabilan, M.K., N. Ahmad and A.M.J. Zainol, 2010. Facebook: An online environment for learning of english in institutions of higher education? Internet and Higher Education, 13(4): 179-187. View at Google Scholar

Kementerian Pendidikan Malaysia, 2008. Pengurusan masa dan gaya pembelajaran.

Khairiyah, M.Y., A.H.S.H. Syed and T. Zaidatun, 2009. Inducting first year engineering students into problem-based learning. Paper Presented at International Symposium on PBL, Republic Polytechnic, Singapure.

Liew, S.C., J. Sidhu and A. Barua, 2015. The relationship between learning preferences (Styles and Approaches) and learning outcomes among pre-clinical undergraduate medical students. BMC Medical Education, 15(1): 44. View at Google Scholar |View at Publisher

Liu, E.S.C., C.J. Ye and D.Y. Yeung, 2014. Effects of approach to learning and self-perceived overall competence on academic performance of university students. Learning and Individual Differences, 39(1): 199-204. View at Google Scholar | View at Publisher

Manca, S. and M. Ranieri, 2013. Is it a tool suitable for learning? A critical review of the literature on facebook as a technology-enhanced learning environment. Journal of Computer Assisted Learning, 29(6): 487-504. View at Google Scholar | View at Publisher 
McManus, I.C., P. Richards, B.C. Winder and K.A. Sproston, 1998. Clinical experience, performance in final examinations, and learning style in medical students: Prospective study. British Medical Journal, 316(7128): 345-350. View at Google Scholar |View at Publisher

Moayyeri, H., 2015. The impact of undergraduate students' learning preferences (VARK Model) on their language achievement. Journal of Language Teaching and Research, 6(1): 132-139. View at Google Scholar | View at Publisher

Mohd, S.M.S. and J.S. Ahmad, 2016. Keberkesanan kaedah pembelajaran teradun melalui media sosial ke atas pencapaian subjek kimia dalam kalangan pelajar Kolej MARA. Paper Presented at National Educational Research Seminar, Kolej MARA Kulim, Kedah.

Newble, D. and E.J. Hejka, 1991. Approaches to learning of medical students and practising physicians: Some empirical evidence and its implications for medical educations. Educational Psychology, 113(3-4): 333-342. View at Google Scholar | View at Publisher

Newble, D.I. and N.J. Entwistle, 1986. Learning styles and approaches: Implications for medical education. Medical Education, 20(3): $162-$ 175. View at Google Scholar | View at Publisher

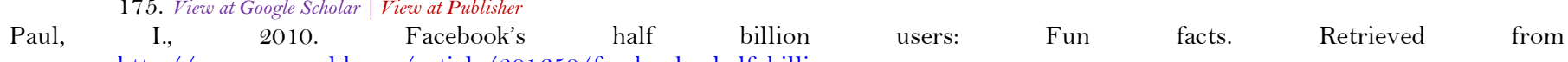
http://www.pcworld.com/article/201650/facebooks_half_billion_users_.

Rainie, L., 2009. Back to the future. Pew Research Center's Internet and American Life Project.

Ramirez, B.U., 2011. The sensory modality used for learning affects grades. Advances in Physiology Education, 35(3): 270-274. View at Google Scholar | View at Publisher

Ramsden, P., 1992. Learning to teach in higher education. London: Routledge.

Sobaih, A.E.E., M.A. Moustafa, P. Ghandforoush and M. Khan, 2016. To use or not to use? Social media in higher education in developing countries. Computers in Human Behavior, 58(1): 296-305. View at Google Scholar

Socialbakers.com, 2015. Malaysia facebook statistics. Retrieved from http://www.socialbakers.com/facebook-statistics/malaysia.

Syed, S.A., P.H.P. Yeow and H.S. Loo, 2011. An empirical study on online social networks sites usage: Online dating sites perspective. International Journal of Business and Management, 6(10): 155-164. View at Google Scholar $\mid$ View at Publisher

Tan, Y.P. and Y.A. Mohammad, 2014. Teacher and student questions: A case study in Malaysian secondary school problem-based learning. Asian Social Science, 10(4): 174-182. View at Google Scholar | View at Publisher

Tess, P.A., 2013. The role of social media in higher education classes (Real and Virtual) - a literature review. Journal of Computers in Human Behavior, 29(5): A60-A68. View at Google Scholar |View at Publisher

Treepuech, W., 2011. The application of using social networking sites with available online tools for teaching and learning management. Paper Presented at IT in Medicine and Education (ITME) 2011, International Symposium, Sapporo, Japan, 5-7 Ogos 2011.

Vygotsky, L.S., 1978. Mind in society: The development of higher psychological processes. Cambridge, Massachusetts: Harvard University Press.

Ward, P.J., 2011. First year medical students' approaches to study and their outcomes in a gross anatomy course. Clinical Ana tomy, 24(1): 120-127. View at Google Scholar | View at Publisher

Watkins, D., 1982. Identifying the study process dimensions of Australian university students. Australian Journal of Education, 26(1): 76-84. View at Google Scholar | View at Publisher

Wiboolyasarin, W., 2014. Blended problem-based instructional model via facebook application on mobile: Are you ready for m-learning? International Journal of e-Education, e-Business, e-Management and e-Learning, 4(2): 91-94. View at Google Scholar | View at Publisher

Wiersma, W., 2000. Research methods in education: An introduction. 7 th Edn., Boston: Allyn \& Bacon. 